\title{
Hubungan Stimulasi Psikososial dengan Perkembangan Anak Usia 3-72 Bulan di Wilayah Kerja Puskesmas Lubuk Begalung Padang
}

\author{
Sri Mulyanti ${ }^{1}$, Eva Chundrayetti ${ }^{2}$, Masrul $^{3}$
}

\begin{abstract}
Abstrak
Perkembangan merupakan salah satu indikator kesehatan anak. Masa 3-72 bulan pertama adalah periode penting untuk mencapai perkembangan optimal anak. Dalam hal ini, stimulasi psikososial berperan dalam merangsang saraf dan otot untuk mencapai perkembangan sesuai dengan umur anak. Tujuan penelitian ini adalah mengetahui hubungan stimulasi psikososial dengan perkembangan anak usia 3-72 bulan di wilayah kerja puskesmas Lubuk Begalung Padang dilakukan penelitian berdesain cross-sectional dengan sampel sebanyak 163 anak berumur 3-72 bulan. Perkembangan anak diukur menggunakan Kuesioner Pra Skrining Perkembangan (KPSP). Stimulasi psikososial diukur menggunakan instrumen Home Observation for Measurement of the Environtment (HOME). Hasil penelitian menunjukkan bahwa $55,8 \%$ anak memiliki perkembangan sesuai, $36,2 \%$ meragukan dan $8,0 \%$ menyimpang. Stimulasi psikosial terbanyak pada kategori sedang sebesar $74,8 \%$. Tidak terdapat hubungan yang signifikan antara stimulasi psikososial dengan perkembangan anak $(p=0,666)$.
\end{abstract}

Kata kunci: stimulasi psikososial, perkembangan, anak usia 3-72 bulan, instrumen HOME dan KPSP

\section{Abstract}

The development is one of the indicators of child health. The first 3-72 months period was crucial for achieving the optimal development of the child. In this case, psychosocial stimulation plays a role in stimulating the nerves and muscles to achieve progress in accordance with the age of the child. The objective of this study was to determine the relationship between psychosocial stimulation and the development of children aged 3-72 months in Lubuk Begalung health center Padang, This research design was a cross-sectional with 163 samples of children aged 3-72 months. Child development was measured by using Pre-Screening Questionnaire Development (KPSP). Psychosocial stimulation was measured by using the Home Observation for Measurement of the Environtment (HOME). The results showed that $55.8 \%$ of children have a good development, $36.2 \%$ doubt and $8.0 \%$ deviated. Most psychosocial stimulation in the intermediate category is $74.8 \%$. There is no significant relationship between psychosocial stimulation with child development $(p=0,666)$.

Key words: psychosocial stimulation, development, children aged 3-72 months, HOME and KPSP instrument

Affiliasi penulis: 1. Prodi Profesi Dokter FK Unand (Fakultas Kedokteran Universitas Andalas Padang). 2. Bagian Anak FK Unand, 3. Bagian Gizi FK Unand

Korespondensi: Sri Mulyanti, Email: cin ajjai7@yahoo.co.id, Telp:082390650876

\section{PENDAHULUAN}

Dua ratus juta anak dibawah usia lima tahun di dunia tidak mencapai potensi perkembangan mereka yang optimal. Sebagian besar anak dengan perkembangan terganggu berasal dari sub-Sahara Afrika (61\%) dan Asia Selatan (52\%). Pada negara berkembang, dari 559 juta anak di bawah 5 tahun, 156 juta di antaranya memiliki perkembangan yang terhambat. Delapan juta anak Indonesia memiliki gangguan perkembangan. Suatu studi persiapan pengembangan pendidikan anak dini usia (PADU) di 5 
propinsi di Indonesia tahun 1997, gangguan perkembangan pada anak usia 3-5 tahun tertinggi di Sumatera Barat, yaitu gangguan perkembangan motorik halus $(57 \%)$, pre-akademik $(81 \%)$ dan sosial (62\%). Prevalensi anak dengan gangguan perkembangan di kota Padang sebesar $12 \%$. Lubuk Begalung adalah kecamatan dengan prevalensi gangguan perkembangan anak tertinggi di kota Padang $(2,69 \%)$. $^{1-3}$

Tingginya prevalensi gangguan perkembangan anak balita di Sumatera Barat berkaitan dengan perubahan hubungan dan sistem kekeluargaan etnik Minangkabau. Perubahan sistem kekeluargaan ini menyebabkan semakin besarnya jumlah ibu yang ikut di sektor ekonomi untuk mendukung ekonomi keluarga. Kondisi ini berdampak semakin sedikitnya waktu ibu dalam mengasuh anak dan berkurangnya dukungan pengasuhan dewasa. Pada tahun 2007 Masrul dalam penelitiannya menyatakan bahwa praktek asuh stimulasi psikososial pada bayi di Sumatera Barat dengan kategori baik hanya $4,5 \%$, kategori sedang $84,9 \%$ dan rendah $10,6 \%{ }^{4-6}$

\section{METODE}

Penelitian ini dilakukan di wilayah kerja puskesmas Lubuk Begalung Padang dari Juli sampai September 2014 dengan sampel berjumlah 163 anak. Anak tersebut merupakan anak usia 3-72 bulan, bersedia untuk berpartisipasi dalam penelitian, berstatus gizi baik serta tidak dalam keadaan sakit dan cacat dengan menggunakan teknik simple random sampling.

Penelitian ini bersifat analitik dengan desain cross sectional. Pengolahan data dilakukan dengan uji statistik Pearson chi-square menggunakan sistem komputerisasi. Variabel bebas dalam penelitian ini adalah pemberian stimulasi psikososial dan variabel tergantung adalah perkembangan anak.

\section{HASIL}

Subyek merupakan anak usia 3-72 bulan di wilayah kerja puskesmas Lubuk Begalung Padang yang memenuhi syarat inklusi.
Tabel 1.Karakteristik responden

\begin{tabular}{|c|c|c|c|}
\hline \multicolumn{2}{|c|}{ Karakteristik Responden } & $f$ & $\%$ \\
\hline \multicolumn{4}{|c|}{ Jenis Kelamin } \\
\hline & laki-laki & 90 & 55,2 \\
\hline & perempuan & 73 & 44,8 \\
\hline \multicolumn{2}{|l|}{ Jumlah } & 163 & 100,0 \\
\hline \multicolumn{4}{|l|}{ Umur } \\
\hline - & $3-12$ bulan & 22 & 13,5 \\
\hline & 12-24 bulan & 16 & 9,8 \\
\hline . & $24-36$ bulan & 49 & 30,1 \\
\hline & $36-48$ bulan & 26 & 15,9 \\
\hline & $48-60$ bulan & 33 & 20,3 \\
\hline . & $63-72$ bulan & 17 & 10,4 \\
\hline \multicolumn{2}{|c|}{$\begin{array}{l}\text { Jumlah } \\
\bar{x}: 36,7 \text { bulan }(\mathrm{SD} \pm 17,6)\end{array}$} & 163 & 100,0 \\
\hline \multicolumn{4}{|c|}{ Jumlah saudara } \\
\hline & 0 & 30 & 18,4 \\
\hline . & 1 & 98 & 60,1 \\
\hline r & 2 & 25 & 15,3 \\
\hline - & 3 & 8 & 4,9 \\
\hline 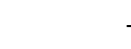 & $>3$ & 2 & 1,2 \\
\hline \multicolumn{2}{|c|}{$\begin{array}{l}\text { Jumlah } \\
\bar{x}: 1,10(\mathrm{SD} \pm 0,79)\end{array}$} & 163 & 100,0 \\
\hline \multicolumn{4}{|c|}{ Pekerjaan Orang Tua } \\
\hline & Buruh & 22 & 13,5 \\
\hline . & PNS & 26 & 15,9 \\
\hline & Pedagang & 30 & 18,4 \\
\hline & Swasta & 83 & 50,9 \\
\hline . & DII & 2 & 1,2 \\
\hline \multicolumn{2}{|l|}{ Jumlah } & 163 & 100,0 \\
\hline \multicolumn{4}{|c|}{ Status Ekonomi per bulan } \\
\hline $\begin{array}{l}-\quad \leq \mathrm{f} \\
-\quad>1 \\
\\
\text { (tic }\end{array}$ & $\begin{array}{l}8,688,- \text { (miskin) } \\
8,688,- \\
\text { skin) }\end{array}$ & 133 & 18,4 \\
\hline $\begin{array}{l}\text { Jumlah } \\
\bar{x}: \text { Rp. } 4 \\
\text { (SD } \pm \text { Rp. }\end{array}$ & $\begin{array}{l}120.07 \\
3.594 .59)\end{array}$ & 163 & 100,0 \\
\hline \multicolumn{4}{|c|}{ Tingkat Pendidikan Orang Tua } \\
\hline \multicolumn{2}{|c|}{ SD/Sederajat } & 4 & 2,5 \\
\hline \multicolumn{2}{|c|}{ - SMP/Sederajat } & 22 & 13,5 \\
\hline \multicolumn{2}{|c|}{ - $\quad$ SMA/Sederajat } & 108 & 66.3 \\
\hline \multicolumn{2}{|c|}{ - $\quad$ Perguruan Tinggi } & 29 & 17.8 \\
\hline \multicolumn{2}{|l|}{ Jumlah } & 163 & 100,0 \\
\hline
\end{tabular}

Pada Tabel 1 dapat diketahui bahwa lebih dari setengah respondenadalah anak laki-laki $(55,2 \%)$, Kelompok umur terbanyak adalah 24-36 bulan dengan 
rerata umur 36,7 bulan (SD $\pm 17,6)$. Responden anak memiliki 1 saudara sebanyak $60,1 \%$ dengan nilai rerata saudara $1,10(S D \pm 0,79)$. Tingkat pendidikan orang tua responden terbanyak adalah SMA/Sederajat. Mayoritas pekerjaan orang tua responden adalah swasta sebanyak $50,9 \%$ dan $81,6 \%$ responden berada di kelompok tidak miskin. Indikator masyarakat miskin kota Padang pada bulan September 2012 adalah masyarakat dengan pendapatan $\leq$ Rp. $348,688 /$ orang/bulan. ${ }^{7}$

Tabel 2. Distribusi frekuensi perkembangan anak

\begin{tabular}{lcr}
\hline \multicolumn{1}{c}{ Pola Perkembangan Anak } & $\mathbf{f}$ & \% \\
\hline Sesuai & 91 & 55,8 \\
Meragukan & 59 & 36,2 \\
Penyimpangan/Delay & 13 & 8,0 \\
\hline
\end{tabular}

Berdasarkan Tabel 2 dapat dilihat bahwa lebih dari setengah responden memiliki perkembangan sesuai.

Tabel 3. Distribusi frekuensi stimulasi psikososial

\begin{tabular}{lcc}
\hline Stimulasi Psikososial & $\mathbf{f}$ & $\%$ \\
\hline Rendah & 28 & 17,2 \\
Sedang & 122 & 74,8 \\
Baik & 13 & 8,0 \\
\hline
\end{tabular}

Berdasarkan Tabel 3 dapat dilihat bahwa stimulasi psikososial paling banyak dalam kategori sedang.

Tabel 4. Hubungan stimulasi psikososial dengan perkembangan anak usia 3-72 bulan

\begin{tabular}{|c|c|c|c|c|c|c|}
\hline \multirow{4}{*}{$\begin{array}{l}\text { Stimulasi } \\
\text { psikososial }\end{array}$} & \multicolumn{4}{|c|}{$\begin{array}{c}\text { Perkembangan } \\
\text { anak }\end{array}$} & \multirow{2}{*}{ Jumlah } & \multirow{4}{*}{$\mathbf{p}$} \\
\hline & \multicolumn{2}{|c|}{ Sesuai } & \multicolumn{2}{|c|}{$\begin{array}{c}\text { Tidak } \\
\text { sesuai }\end{array}$} & & \\
\hline & & $n$ & & n & $n$ & \\
\hline & & $\%$ & & $\%$ & $\%$ & \\
\hline Baik & 8 & 61,5 & 5 & 38,5 & $\begin{array}{ll}13 & 100\end{array}$ & \\
\hline Tidak baik & 83 & 55,3 & 67 & 44,7 & $150 \quad 100$ & 0,666 \\
\hline
\end{tabular}

Berdasarkan Tabel 4 dapat dilihat bahwa anak dengan stimulasi psikososial baik memiliki perkembangan sesuai lebih banyak dibandingkan perkembangan tidak sesuai. Dari tabel tersebut juga tampak stimulasi psikososial tidak baik lebih banyak memiliki perkembangan yang sesuai dibandingkan perkembangan tidak sesuai. Hasil uji statistik menunjukkan perbedaan ini tidak memiliki makna $(p>0,05)$.

\section{PEMBAHASAN}

\section{Perkembangan Anak}

Perkembangan (development) adalah pertambahan kemampuan struktur dan fungsi tubuh yang lebih kompleks, menyangkut adanya proses diferensiasi sel, jaringan, organ dan sistem organ yang berkembang sedemikian rupa sehingga masingmasing dapat memenuhi fungsinya. ${ }^{8}$

Pada Tabel 2 dapat dilihat bahwa masih ditemukan anak usia 3-72 bulan dengan gangguan perkembangan di wilayah kerja puskesmas Lubuk Begalung. Gangguan perkembangan ini dapat disebabkan oleh berbagai macam faktor. salah satunya adalah faktor ekonomi. Pendapatan yang memadai dapat memenuhi kebutuhan gizi dan perlengkapan yang dapat menyokong perkembangan anak. Faktor berikut adalah kurangnya pengetahuan ibu tentang asuhan untuk mencapai perkembangan optimal anak. ${ }^{9}$

\section{Stimulasi Psikososial}

Stimulasi psikososial merupakan cikal bakal proses pembelajaran anak melalui pendidikan dan pelatihan. Melalui stimulasi psikososial, anak dapat mengendalikan dan mengkoordinasikan otot-ototnya serta melibatkan perasaan emosi dan pikiran sehingga anak mendapat berbagai pengalaman hidup. ${ }^{10}$

Hasil penelitian ini mendapatkan bahwa sebagian besar stimulasi psikososial berada dalam kategori sedang sebanyak $74,8 \%$. Hasil penelitian ini sesuai dengan hasil penelitian Masrul pada tahun 2007 yang menyatakan bahwa stimulasi psikososial anak di Sumatera Barat paling banyak dalam kategori sedang sebesar $84,9 \%{ }^{6}$ Hal ini dapat disebabkan karena ibu/pengasuh lebih banyak menyediakan waktu untuk mengasuh anak. ${ }^{11}$ 


\section{Hubungan Stimulasi Psikososial dengan \\ Perkembangan Anak Usia 3-72 Bulan}

Pada hasil tabulasi silang Tabel 4 antara stimulasi psikososial dengan perkembangan anak usia 3-72 bulan dapat diketahui bahwa tidak terdapat hubungan yang bermakna antara stimulasi psikososial dengan perkembangan anak usia 3-72 bulan di wilayah kerja puskesmas Lubuk Begalung Padang $(p=0,666, p>0,05)$. Hal ini disebabkan oleh status gizi responden pada kategori baik yang terbukti dari pengukuran berat badan dan tinggi badan menggunakan grafik Z-Score dan sebagian besar keadaan ekonomi keluarganya tidak miskin.

Penelitian yang dilakukan oleh Riyani Lubis ditahun 2008 pada anak balita di wilayah kerja puskesmas Pantai Cermin kecamatan Tanjung Pura, Langkat, Sumatera Utara juga menunjukkan hasil yang sama yaitu tidak terdapat hubungan yang bermakna antara stimulasi psikososial dengan perkembangan anak balita. ${ }^{12}$

Hal ini berbeda dengan pendapat Februhartanty et al yang dikemukakan pada tahun 2007 bahwa rangsangan psikososial yang baik berkaitan dengan kesehatan anak sehingga secara tidak langsung dapat mempengaruhi status perkembangan anak. Kualitas stimulasi psikososial ini sendiri tergangtung dari keadaan keluarga, masyarakat serta lingkungan. ${ }^{13}$

Penelitian Wiwin et al tahun 2008 juga menemukan ada pengaruh stimulasi perkembangan terhadap perkembangan anak $(p=0,000){ }^{14}$

Pada tahun 2008 Giyarti meneliti mengenai pengaruh stimulasi psikososial, perkembangan kognitif dan perkembangan sosial emosi terhadap perkembangan bahasa anak usia prasekolah di kabupaten Bogor. Dari penelitian tersebut didapatkan terdapat hubungan positif antara pendidikan ibu dan pendapatan keluarga dengan stimulasi psikososial dan subskala stimulasi belajar serta penerimaan; antara usia dengan subskala kehangatan dan penerimaan;dan antara pendapatan keluarga dengan subskala lingkungan fisik $(p>0,1)$. Terdapat hubungan negatif antara besar keluarga dengan stimulasi psikososial, subskala stimulasi belajar, modeling, dan variasi pengalaman dan antara usia dengan subskala kehangatan dan penerimaan $(p>0,1)$. Adanya hubungan negatif antara subskala modeling dengan perkembangan sosial emosi $(p>0,1)$. Terdapat hubungan positif antara subskala penerimaan dengan perkembangan sosial emosi dan antara stimulasi psikososial, subskala stimulasi belajar, modeling, dan variasi pengalaman dengan perkembangan bahasa anak $(p>0,1)$. Ada dua faktor yang berpengaruh positif terhadap perkembangan bahasa anak usia prasekolah, yaitu stimulasi bahasa dan perkembangan kognitif. ${ }^{15}$

Perbedaan hasil penelitian bisa terjadi karena banyak faktor yang mempengaruhi perkembangan anak seperti faktor genetik, gizi, stimulasi psikososial, motivasi belajar, ganjaran atau hukuman yang wajar, kelompok sebaya, tingkat stress, cinta dan kasih sayang yang diperoleh anak, kualitas interaksi orang tua, status ekonomi keluarga, tingkat pendidikan orang tua, jumlah saudara, stabilitas rumah tangga, ajaran agama dan sebagainya.

\section{SIMPULAN}

Tidak terdapat hubungan yang bermakna antara stimulasi psikososial dengan perkembangan anak usia 3-72 bulan di wilayah kerja puskesmas Lubuk Begalung Padang.

\section{DAFTAR PUSTAKA}

1. Gr-McGregor S, Yin BC, Santiago C. Developmental potential in the first 5 years for children in developing countries based on WHO and UNICEF database from 1985-February 2006 (diunduh 25 Februari 2014).Tersedia dari: URL: HYPERLINK http:// www.thelancet.com.

2. Depkes RI. Riset kesehatan dasar (Riskesdas) 2007. Jakarta; 2007.

3. Dinkes Kota Padang. Laporan tahunan program kesehatan ibu dan anak (KIA) 2013. Padang; 2013.

4. Rajab M. System kekerabatan di Minangkabau: Center For Minangkabau Studies Padang; 1968.

5. Kato T. Nasab ibu dan marantau: tradisi Minangkabau yang berterusan di Indonesia. Malaysia: Dewan Bahasa dan Pustaka; 1989.hlm. 138-224. 
6. Masrul. Ringkasan disertasi kajian peranan sumber daya pengasuhan terhadap tumbuh kembang bayi usia 6-12 bulan pada keluarga etnik Minangkabau di pedesaan Propinsi Sumatera Barat. Surabaya: Program Pascasarjana Universitas Airlangga; 2007.

7. Badan Pusat Statistik Provinsi Sumatera Barat. Indikator masyarakat miskin Kota Padang pada bulan September 2012. Padang; 2013.

8. Pamilu A. Mengoptimalkan keajaiban otak kanan dan otak kiri anak. Magelang: Pustaka Horizona; 2008.

9. Adisasmito W. Sistem kesehatan. Jakarta: PT Raja Grafindo Persada; 2007.

10. Soetjiningsih. Tumbuh kembang anak. Jakarta: EGC; 1995.

11. Engle PL, Menon P, Hadad L. Care and Nutrition: Conceps and measurements. Washington D.C: FCND Discussion Paper No.18; 1997.

12. Lubis R. Hubungan pola asuh dengan status perkembangan anak balita di wilayah kerja
Puskesmas Pantai Cermin Kecamatan Tanjung Pura Kabupaten Langkat Tahun 2008 (skripsi). Medan: Fakultas Kesehatan Masyarakat Universitas Sumatera Utara; 2008.

13. Februhartanty J, Usfar AA, Dianawati E, Fransisca DO, Roshita A, Fahmida U. Psycosocial care and nutritional status of children aged 6-36 months among patrilinear (Karo) and matrilinear (Minangkabau) households in Jakarta. Asia Pacific Journal Clinic Nutrition. 2007;16(2):293-300.

14. Wiwin $M$, Setijaningsih $T$, Winarni $S$. Pengaruh stimulasi psikososial terhadap Perkembangan Anak Sebagai Tindak Lanjut DDTKA Masal Pasca Pencatatan Rekor Muri Di Kota Blitar. Malang: Repository Program Studi Keperawatan Blitar, Poltekkes Depkes Malang; 2008.

15. Giyarti. Pengaruh stimulasi psikososial, perkembangan kognitif, dan perkembangan sosial emosi terhadap perkembangan bahasa anak usia prasekolah di Kabupaten Bogor (skripsi). Bogor: Repository Institut Pertanian Bogor; 2008. 